\title{
PELAKSANAAN PERLINDUNGAN HUKUM BAGI PEMILIK HAK CIPTA MUSIK DAN LAGU DALAM PEMBAYARAN ROYALTI OLEH YAYASAN KARYA CIPTA INDONESIA
}

\author{
Ni Made Harini, I Nyoman Putu Budiartha, Desak Gde Dwi Arini \\ Fakultas Ilmu Hukum Universitas Warmadewa, Denpasar-Bali, Indonesia \\ arinmahardika1@yahoo com, budiarthaputu59@gmail com, arinidesak1966@gmail com
}

\begin{abstract}
Abstrak
Hak cipta memberikan hak milik eksklusif atas suatu karya si pencipta yang diberikan oleh hukum sebagai suatu penghargaan. Fungsi hak cipta melindungi pencipta dari pelanggaran hak cipta. Penelitian ini bertujuan untuk menjelaskan bentuk perlindungan hukum pemilik hak cipta musik dan lagu dalam pembayaran royalti oleh yayasan karya cipta Indonesia dan mendeskripsikan faktor-faktor apakah yang mempengaruhi pembayaran royalti dan upaya penyelesaian sengketa yang dihadapi pemegang hak cipta musik dan lagu dalam pembayaran royalti oleh yayasan karya cipta Indonesia. Tipe penelitian ini adalah penelitian hukum empiris dengan pendekatan masalah perundang-undangan konseptual fakta dan sosiologis. Adapun sumber data yang digunakan adalah bahan hukum primer dan sekunder. Hasil penelitian mengatakan bahwa hak cipta diatur dalam UndangUndang Nomor 28 Tahun 2014 tentang Hak Cipta. Bentuk perlindungan hukum hak cipta yakni perlindungan hukum hak moral dan perlindungan hukum hak ekonomi Pencipta dan Yayasan KCI mempunyai hak dan kewajiban, didalam proses pembayaran royalti mengalami beberapa hambatan dan pendukung yang dialami Yayasan KCI pencipta dan pengguna hak cipta. Upaya penyelesaian sengketa melalui alternatif penyelesaian sengketa arbitrase dan pengadilan
\end{abstract}

Kata Kunci: Hak Cipta, Perlindungan Hukum, Royalti Yayasan KCI

\begin{abstract}
Copyright gives an exclusive title to the work of the author which is granted by law as an award. The copyright function protects creators from copyright infringement. This study aims to explain the form of legal protection for music and song copyright owners in royalty payments by the Indonesian copyright works foundation and to describe what factors influence royalty payments and dispute resolution efforts faced by music and song copyright holders in royalty payments by the Karya Foundation. Indonesian copyright. This type of research is an empirical legal research with a conceptual approach to legal issues of fact and sociology. The data sources used were primary and secondary legal materials. The results of the study indicated that copyright is regulated in Law Number 28 of 2014 concerning Copyright. The form of copyright law protection, namely legal protection of moral rights and legal protection of economic rights. Creators and the KCI Foundation have rights and obligations, in the process of paying royalties experiencing several obstacles and supporters experienced by the KCI Foundation creators and copyright users. Dispute settlement efforts through alternative arbitration and court dispute resolution.
\end{abstract}

Keywords: Copyright, Legal Protection, Royalties for the KCI Foundation

\section{PENDAHULUAN}

Karya lagu atau musik adalah ciptaan yang terdiri dari lagu atau melodi syair lirik dan aransemen (Marbun, Azwar, \& Windha, 2013). Suatu karya cipta mampu memberikan kepuasan tersendiri bagi penikmat musik dan lagu yang didengarkan dalam bentuk nada, musik dan lagu memiliki potensi ekonomi yang sangat besar di Indonesia (Khoiriyah \& Sinaga, 2017; Sujayanthi \& Putraka, 2018). Secara khususnya di Bali peningkatan daya beli masyarakat terhadap karya musik memberikan manfaat ekonomi bagi penciptanya. Hak cipta memberikan hak eksklusif bagi pencipta atas suatu karya ciptanya diberikan oleh hukum sebagai suatu penghargaan dikarenakan menghasilkan suatu karya dibutuhkan tenaga waktu pikiran dan bahkan biaya.

Hak ekonomi pemegang hak cipta diatur dalam Undang-Undang Dasar Tahun 1945 Pasal 33 namun masih banyak oknum-oknum pengguna karya cipta yang melanggar hak pencipta atas 
ciptaannya dengan tidak membayar royalti dan tidak meminta izin atas penggunaan ciptaan. Terjadinya pelanggaran tersebut berpengaruh terhadap produktivitas pencipta dalam menghasilkan karya baru (Hasibuan, 2008). Maraknya pelanggaran hak cipta karena kurang diketahuinya UndangUndang Hak Cipta yakni Undang-Undang Nomor 28 Tahun 2014 tentang Hak Cipta Masyarakat kurang berminat membaca peraturan dan minimnya penyuluhan mengenai hak cipta Lemahnya perlindungan hukum di Indonesia sebagai akibat lemahnya oleh peraturan penegakan hukum itu sendiri (Gautama, 1990). Upaya perlindungan hak cipta di Indonesia berdiri lembaga manajemen kolektif dikenal sebagai lembaga untuk mengumpulkan royalti bagi pencipta lagu adalah Karya Cipta Indonesia selanjutnya disingkat $(\mathrm{KCI}), \mathrm{KCI}$ sebagai pengelola hak eksklusif para pencipta musik dan lagu baik berasal dari luar atau dalam negeri KCI adalah badan hukum Nirlaba berbentuk Yayasan KCI dalam menjalankan tugas harus memiliki landasan hukum yang jelas jika landasan itu tidak ada maka sangat memungkinkan banyak pihak yang menentang keberadaan KCI itu sendiri. Dari hasil observasi pada tanggal 14 Oktober 2020 oleh bapak Enteng Tanamal selaku pendiri dan pembina Yayasan Karya Cipta Indonesia bahwa salah satu isu hukum yang perlu mendapat perhatian khusus dalam hal ini yakni hotel restoran serta tempat hiburan seperti karaoke di Bali yang melanggar pembayaran royalti karya cipta musik dan lagu dalam 10 tahun terakhir yayasan KCI sudah banyak menemukan pelanggaran karya cipta khususnya di Bali diperkirakan di atas 95\% hotel dan restoran maupun tempat hiburan belum membayar hak cipta tentunya hal ini sangat merugikan bagi pemegang hak cipta musik dan lagu

Ada beberapa penelitian terdahulu yang melakukan penelitian relevan dengan penelitian ini, yaitu Maramis, (2014); (Kusno, 2017); (Sutikno \& Jannah, 2019) megungkapkan Perlindungan hak cipta harus dilkukan secara hukum administrasi negara, hukum harus hadir menjamin perlindungan hak cipta pencipta guna menghindari sikap plagiarisme lagu yang diunduh baik melalui kaset maupun lewat internet internet dapat dilakukan dengan upaya preventif dan represif. Walaupun permasalahan ini pernah diteliti sebelumnya, akan tetapi melakukan penelitian dengan metode penyajian masalah yang berbeda. Penelitian ini bertujuan untuk menjelaskan bentuk perlindungan hukum pemilik hak cipta musik dan lagu dalam pembayaran royalti oleh yayasan karya cipta Indonesia dan mendeskripsikan faktor-faktor apakah yang mempengaruhi pembayaran royalti dan upaya penyelesaian sengketa yang dihadapi pemegang hak cipta musik dan lagu dalam pembayaran royalti oleh yayasan karya cipta Indonesia

\section{METODE}

Penelitian ini didesain menggunakan penelitian empiris dimana yaitu penelitian lapangan. Pendekatan yang digunakan yakni pendekatan Undang-Undang (statue approach), pendekatan konseptual (conceptual approach) pendekatan fakta (the fact approach), dan pendekatan sosiologis. Sumber data yang digunakan sebagai data primer data yang diperoleh dari hasil observasi sumber pertama berupa dari pengamatan lapangan melalui wawancara yang selanjutnya dianalisis. Data sekunder data yang diperoleh melalui studi kepustakaan berupa peraturan Perundang-Undangan buku-buku maupun. Data sekunder yang digunakan berupa bahan hukum primer Undang-Undang Dasar Negara Republik Indonesia Tahun 1945 Kitab Undang-Undang Hukum Perdata (KUH Perdata) Buku III UndangUndang Nomor 28 Tahun 2014 Tentang Hak Cipta. Lokasi penelitian sebagai tempat objek penelitian adalah Kantor KCI Jalan Gunung Lumut Nomor 65 Gang Kenari 1 Teuku Umar Denpasar Barat Bali selaku pihak yang berwenang dalam pembayaran royalti. Teknik pengumpulan data menggunakan penelitian dengan teknik wawancara teknik pencatatan membaca buku-buku peraturan perundangundangan serta literatur. Analisis data menggunakan metode deskriptif kualitatif (Sugiyono, 2013).

\section{HASIL DAN PEMBAHASAN}

\section{Bentuk Perlindungan Hukum bagi Pemilik Hak Cipta Musik dan Lagu}

Hak cipta merupakan hak eksklusif yang diberikan kepada pencipta hak cipta timbul secara otomatis berdasarkan prinsip deklaratif setelah ciptaan diwujudkan dalam bentuk nyata tanpa mengurangi pembatasan sesuai peraturan perundang-undangan hal ini terdapat pada pasal 1 ayat 1 UndangUndang Nomor 28 Tahun 2014 Tentang Hak Cipta Hak cipta terdiri atas hak dan cipta hak yang berarti kewajiban atas suatu kewenangan cipta adalah hasil kreasi manusia berupa pikiran perasaan pengetahuan dan pengalaman Karena itu berkaitan dengan intelektualitas manusia itu sendiri berupa hasil kerja otak (Bintang, 1998). 
Hak cipta terdiri atas hak moral dan hak ekonomi hak ekonomi adalah hak yang melindungi kepentingan pribadi si pencipta hal ini terdapat pada pasal 5 Undang-Undang Nomor 28 Tahun 2014 tentang Hak Cipta. Hak moral dibagi menjadi dua yakni hak untuk diakui sebagai pencipta dalam hal ini hak moral identitas pencipta harus dicantumkan dalam ciptaan baik nama diri maupun samaran. Hak keutuhan karya hak yang menyangkut segala bentuk sikap dan perlakuan terkait dengan integritas pencipta hak tersebut diekspresikan dalam bentuk merusak ciptaaan atau mengubah ciptaan (Hutagalung, 2012). Hak ekonomi adalah hak seseorang untuk mendapatkan keuntungan atas ciptaannya pencipta melakukan perbanyakan ciptaan kemudian dijual di pasaran maka ia memperoleh keuntungan materi (Supramono, 2010). Salah satu hal yang perlu disepakati dalam hak cipta yakni kompensasi kompensasi yang dimaksud adalah royalti. Royalti adalah bentuk pembayaran sebagai pemanfaatan suatu ciptaan yang diterima oleh pencipta. Royalti dibedakan menjadi dua yakni royalti (royalty payment) pembayaran secara bertahap mengikuti omset penjualan secara terus menerus selama produk dijual di pasaran dan jenis flat (flat payment) pembayaran sekaligus pembayaran ini ditentukan jumlah dan jangka waktu peredarannya Royalti diberikan kepada pencipta dengan dipotong biaya administrasi kepada Yayasan KCI 30\% (tiga puluh persen dan 70\% (tujuh puluh persen) kepada pencipta. Royalti didistribusikan setiap tahunnya

Sesuai wawancara pada tanggal 12 November 2020 oleh Bapak A A Raka Danu Drs I Gede Eka Putra Bapak Nyoman Arya Kusuma Bapak I Ketut Widiana dan Ibu Ni Made Suastini selaku pencipta lagu bali mengatakan bahwa pencipta mempunyai hak dan kewajiban. Hak pencipta mempunyai ha katas ciptaan pencipta berhak menuntut siapa saja yang menggunakan karyanya tanpa izin hak untuk mendapatkan royalti dari KCI setiap setahun sekali Kewajiban pencipta yakni wajib menciptakan suatu karya agar karya tersebut dapat didaftarkan dan mendapatkan hak ekonomi berupa royalti

Perlindungan hukum bagi pencipta sangat penting dikarenakan masih maraknya pelanggaran atas hak cipta yang tingkat pembajakannya cukup besar. Keadaan tersebut menunjukan bahwa pentingnya perlindungan hukum yang tegas yang berhubungan dengan royalti karya cipta musik dan lagu. Bentuk perlindungan hukum dibedakan menjadi bentuk perlindungan hukum preventif upaya menghindari terjadinya sengketa dan bentuk perlindungan hukum represif upaya penyelesaian terjadinya sengketa Bentuk perlindungan hukum menurut Undang-Undang Hak cipta yakni perlindungan terhadap hak moral dan perlindungan terhadap hak ekonomi. Perlindungan hukum yakni ada dua yakni bentuk perlindungan hukum preventif dan bentuk perlindungan hukum represif. Perlindungan hukum preventif yakni upaya yang dilakukan untuk menghindari adanya sengketa hak cipta musik dan lagu yang terdapat hak dan kewajiban pencipta selaku pemegang hak cipta serta hak dan kewajiban Yayasan KCI selaku pemberi royalti sedangkan perlindungan hukum represif yakni upaya yang dilakukan jika terjadinya sengketa apabila pengguna karya cipta tidak meminta izin untuk menggunakan karya cipta orang lain atau tidak membayar royalti sebagaimana telah disepakati sebelumnya.

\section{Faktor yang Mempengaruhi Pembayaran Royalti dan Upaya Penyelesaian Sengketa yang Dihadapi Pemegang Hak Cipta Musik dan Lagu}

Pelaksanaan pembayaran royalti atas karya cipta oleh KCI kepada pencipta musik dan lagu mengalami beberapa permasalahan yang menyebabkan terhambatnya pembayaran royalti tersebut. Pemungutan royalti tersebut memang sudah dikuasai kepada KCI yang diberikan oleh pencipta atau pemegang hak cipta. Berdasarkan hasil wawancara pada tanggal 12 November 2020 oleh Ibu Yoan Tanamal selaku Ketua Yayasan KCI Provinsi Bali mengatakan ada beberapa faktor-faktor yang menyebabkan terhambatnya pembayaran royalti yakni

1. Tempat usaha tutup dikarenakan pandemi Banyaknya tempat usaha dikarenakan Covid-19 seperti cafe restaurant dan hotel memperhambat KCI untuk memungut royalti oleh pihal pengguna ciptaan

2. Ketidaktahuan pihak pengguna karya cipta tentang royalti Banyaknya pengguna karya cipta yang tidak menghiraukan mengenai hak cipta dan royalti yang menjadikan pelanggaran hak cipta semakin hari semakin meningkatKurangnya kesadaran pencipta atau penerima lisensi

3. Pentingnya suatu pendaftaran hak cipta sebagai pemberi status hukum atas karya cipta tujuan pendaftaran tersebut untuk pembuktian apabila dikemudian hari terjadi sengketa Didalam pembayaran royalti adanya keterkaitan Yayasan KCI dengan pengguna karya cipta atau pengusaha cafe restaurant dan hotel 
Selanjutnya wawancara pada tanggal 13 November 2020 oleh Bapak Marchellino Bapak Made Agus Perdana Kristapa dan Bapak I Gst Made Putra Adnyana Kusuma selaku pengguna karya cipta yang memiliki usaha café mengatakan bahwa ada beberapa faktor yang menjadi hambatan pembayaran royalti oleh pengguna karya cipta yaitu

1. Kurangnya sosialisasi yang dilakukan oleh Yayasan KCI mengenai royalti Keberadaan Yayasan $\mathrm{KCI}$ dan atas asas apa Yayasan KCI dapat memungut royalti masih sering menjadi pertanyaan pengguna karya cipta Hal itu menjadi keraguan pengguna ciptaan untuk membayar royalti sehingga masih ada pengguna ciptaan menolak membayar royalti

2. Minimnya biaya operasional Sebelum adanya pandemi banyak tempat usaha yang minim biaya operasional dikarenakan sedikitnya pengunjung timbah adanya Covid-19 semakin mempersulit tempat usaha untuk biaya operasional

Selain faktor hambatan adapun faktor pendukung yang mempermudah proses pembayaran royalti Berdasarkan hasil wawancara pada tanggal 12 November 2020 oleh Ibu Yoan Tanamal selaku Ketua Yayasan KCI Provinsi Bali ada beberapa faktor pendukung dalam pembayaran royalti, yaitu:

1. Pemerintah Didalam proses pembayaran royalti pemerintah ikut serta dalam pemungutan royalti bersama KCI bertujuan untuk jika adanya perselisihan dari pihak KCI dengan pemilik usaha maka pemerintah dapat bersifat netral Dengan dasar hukum yang kuat mengenai royalti dan mengenai sanksi-sanksi ketentuan pidana maka tidak ada lagi alasan pemilik usaha untuk tidak membayar royalti

2. Pencipta atau pemegang hak cipta. Adanya pendaftaran atas ciptaan mempermudah KCI untuk memperoleh hak ekonomi berupa royalti Keberadaan sosial media menjadi faktor pendukung dalam mensosialisasikan mengenai hak-hak yang didapat oleh pencipta

3. Sarana pendukung penegakan hukum. Sarana yang penting pada proses penegakan hukum yakni tenaga manusia Tenaga manusia yang ahli dibidangnya mempermudah Yayasan KCI untuk membuat efektivitas dalam menjalankan tugas dan wewenang dalam memungut dan menghitung royalti lebih efisien.

Sebagai pemegang hak cipta kekecewaan tentu akan dirasakan apabila melihat pihak lain mengkalim karya tersebut miliknya. Berdasarkan Undang- Undang Hak Cipta semua pihak berkewajiban meminta izin dan membayar royalti apabila suatu karya digunakan untuk keperluan komersial. Pelanggaran terhadap hak cipta sering dilakukan oleh pengguna ciptaan berupa memperbanyak musik dan lagu tanpa izin resmi dan melanggar perjanjian lisensi. Apabila terbukti melanggar maka pelanggar harus dihukum baik secara perdata maupun pidana Jika pihak pengguna melanggar hak cipta Yayasan KCI tidak secara langsung melaporkan kepada pihal berwajib untuk diproses hukum namun dengan penyelesaian yang tercantum di dalam perjanjian. Berdasarkan hasil wawancara pada tanggal 12 November 2020 oleh Ibu Yoan Tanamal selaku Ketua Yayasan KCI Provinsi Bali bahwa sistem sosialisasi yang dilakukan KCI dengan door to door mendatangi setiap pengguna karya cipta Sistem tersebut dilakukan dengan cara mengirim surat Macam-macam surat yang diberikan secara bertahap oleh KCI jika pengguna karya cipta tetap tidak menghiraukan Surat tersebut dibagi menjadi

1. Introduction Letter (surat pemberitahuan )

Surat yang berisikan hak cipta bahwa ciptaan dilindungi oleh Undang- Undang

2. Reminder Letter (surat pengingat)

Surat yang bertujuan untuk mengingatkan pengguna karya cipta mempunyain kewajiban yang jika dilanggar berakibat hukum

3. Warning Letter ( surat peringatan )

Surat peringatan diberikan jika pengguna karya cipta tetap tidak menghiraukan surat yang diberikan KCI

Penyelesaian sengketa hak cipta dapat dilakukan melalui alternatif penyelesaian sengketa arbitrase dan pengadilan. Alternatif penyelesaian sengketa hanya sebatas mediasi negosiasi dan konsiliasi. Mediasi adalah intervensi oleh pihak ketiga yang netral dalam membantu penyelesaian sengketa para pihak yang berselisih untuk mencapai kesepakatan secara sukarela (Susanti Adi Nugroho 2015 41). Negosiasi adalah penyelesaian masalah antara para pihak dengan suatu proses tawar menawar untuk mencapai suatu kesepakatan. Konsiliasi adalah penyelesaian sengketa yang melibatkan pihak ketiga yaitu konsiliator Namun kesepakatan dan keputusan sepenuhnya dilakukan oleh para pihak konsiliator 
menyampaikan pesan dari satu pihak ke pihak lain jika tidak memungkinkan disampaikan langsung oleh pihak yang bersengketa (Joni Emirxon 2000 67)

Arbitrase merupakan penyelesaian sengketa diluar pengadilan yang didasarkan perjanjian arbitrase secara tertulis yang dibuat oleh para pihak dengan memuat klausula arbitrase sebelum terjadi sengketa (Pactum Compromittendo) maupun setelah terjadinya sengketa (Acta Compromise). Pengadilan yang berwenang mengadili sengketa pelanggaran hak cipta adalah Pengadilan Niaga dalam hal pengajuan gugatan. Pengadilan Niaga adalah Pengadilan khusus yang dibentuk dilingkungan peradilan umum yang berwenang memeriksa mengadili dan memberi putusan terhadap perkara kepailitan pembuktian verifikasi utang sengketa kepailitan dan hak kekayaan intelektual yang salah satunya meliputi sengketa hak cipta. Dari hal tersebut diatas diketahui bahwa Yayasan KCI selaku pemberi royalti mempunyai hambatan dan pendukung dalam pembayaran royalti yakni hambatannya tempat usaha tutup dikarenakan pandemi ketidaktahuan pengguna hak cipta mengenai royalti, biaya operasional yang sangat minim, kurangnya petugas pengawas dan kurangnya kesadaran pencipta. Untuk mendaftarkan ciptaannya sedangkan pendukungnya pada pemerintah dikarenakan dengan adanya Undang-Undang pemerintah dapat membantu proses pemungutan royalti dan pendukungnya ada pada pencipta itu sendiri dikarenakan adanya pencipta yang mendaftarkan ciptaan mempermudah Yayasan KCI untuk memungut royalti tersebut. Upaya penyelesaian jika terjadi sengketa diatur dalam Pasal 95 Ayat (1) dan Ayat (2) Undang-Undang Nomor 28 Tahun 2014 tentang Hak Cipta Penyelesaian sengketa Hak Cipta dapat dilakukan melalui alternatif penyelesaian sengketa arbitrase dan yang terakhir pengadilan

\section{SIMPULAN DAN SARAN}

\section{Simpulan}

Dari hasil analisis di atas, dapat disimpul bahwa bentuk. Bentuk perlindungan hukum ada dua yakni perlindungan hukum preventif upaya yang dilakukan untuk menghindari sengketa dan perlindungan hukum represif. Pencipta selaku pihak yang menerima royalti dan pihak yang mempunyai karya mempunyai hak dan kewajiban atas ciptaannya dan Yayasan KCI selaku pemberi royalti juga mempunyai hak dan kewajiban dalam pembayaran royalti kepada pencipta, yang kedua faktor hambatan yang dihadapi Yayasan KCI yakni kurangnya kesadaran pencipta untuk pentingnya suatu karya cipta didaftarkan jika dikemudian hari terjadi sengketa dan kurangnya sosialisasi oleh Yayasan KCI mengenai royalti. Selanjutnya faktor pendukungnya yakni dengan dasar hukum yang kuat mengenai royalti menjadikan faktor pendukung dari pemerintah yang dapat mempermudah proses pembayaran royalti. Berdasarkan Undang-Undang Hak Cipta semua pihak yang menggunakan karya cipta berupa lagu milik orang lain maka orang tersebut berkewajiban membayar royalti apabila digunakan untuk keperluan komersial. Penyelesaian sengketa dapat dilakukan melalui alternatif penyelesaian sengketa (mediasi negosiasi dan konsiliasi) arbitrase dan yang terakhir pengadilan Pengadilan yang berwenang mengadili penyelesaian sengketa Hak Cipta yakni Pengadilan Niaga.

\section{Saran}

Berdasarkan hasil penelitian, saran yang dapat disampaikan adalah kepada pemerintah agar lebih tegas dalam menangani masalah pelanggaran Hak Cipta dan pentingnya sosialisasi yang diberikan kepada masyarakat untuk meminimalisir terjadinya pelanggaran. Kepada pemegang atau pencipta musik dan lagu agar melakukan pendaftaran atas ciptaannya meskipun bersifat tidak wajib hal ini dilakukan untuk mencegah terjadi sengketa pelanggaran hak cipta. Kepada masyarakat agar lebih mengetahui apa itu Hak Cipta dan royalti itu sendiri sebagai bentuk dukungan dan apresiasi penghargaan kepada pencipta karya musik dan lagu yang memberikan dampak baik untuk negara

\section{DAFTAR PUSTAKA}

Bintang, S. (1998). Hukum Hak Cipta (1st ed.). Bandung: Citra Aditya Bakti.

Gautama, S. (1990). Segi-Segi Hukum Hak Milik Intelektual. Bandung: Eresco.

Hasibuan, O. (2008). Hak Cipta di Indonesia Tinjauan Khusus Hak Cipta Lagu Neighbouring Rights dan Collecting Society. Bandung: Alumni.

Hutagalung, S. M. (2012). Hak Cipta: Kedudukan dan Peranannya dalam Pembangunan. Jakarta Timur: Pena Grafika.

Khoiriyah, N., \& Sinaga, S. S. (2017). Pemanfaatan Pemutaran Musik terhadap Psikologis Pasien pada Klinik 
Ellena Skin Care di Kota Surakarta. Jurnal Seni Musik, 6(2), 81-90.

Maramis, R. L. (2014). Perlindungan Hukum Hak Cipta Atas Karya Musik dan Lagu dalam Hubungan dengan Pembayaran Royalti. Lex Privatum, 2(2), 116-125.

Marbun, T. H., Azwar, T. K. D., \& Windha. (2013). Perlindungan Hukum Hak Cipta Terhadap Karya Cipta Lagu Dan Musik dalam Bentuk Ringtone Pada Telepon Seluler. TJurnal Hukum Ekonom, 1(1), 1-6.

Sugiyono. (2013). Metode Penelitian Pendidikan Pendekatan Kuantitatif dan Kualitatif. Bandung: Alfabeta.

Sujayanthi, N. W. M., \& Putraka, A. N. A. (2018). Perlindungan Hukum Terhadap Alat Musik Tradisional Bali. Jurnal Seni Pertunjukan, 4(2), 105-111.

Supramono, G. (2010). Hak Cipta dan Aspek-Aspek Hukumnya. Jakarta: Rineka Cipta.

Sutikno, F. M., \& Jannah, I. D. M. (2019). Perlindungan Hukum Hak Cipta Lagu di Indonesia dan Malaysia. Jurnal Literasi Hukum, 3(1), 14-25. 